\section{Vietnam Journal of Agricultural Sciences}

\title{
Variations in Growth Performance and Nitrogen Uptake of Sugarcane Cultivars Under Rain-Fed Conditions
}

\author{
Dinh Thai Hoang ${ }^{1}$, Hiroo Takaragawa², Le Trong Lu², Eizo \\ Taira $^{2}$ \& Yoshinobu Kawamitsu²
}

${ }^{1}$ Faculty of Agronomy, Vietnam National University of Agriculture, Hanoi 131000 , Vietnam

${ }^{2}$ Faculty of Agriculture, University of the Ryukyus, Okinawa 903-0213, Japan

\begin{abstract}
The experiment was conducted to evaluate growth and nitrogen uptake of the twelve sugarcane varieties, viz. NiF3, NiF8, Ni9, Ni12, Ni15, Ni17, Ni21, Ni22, Ni25, Ni27, Ni28, and Ni29, under rain-fed conditions during the period from 70 to 160 days after transplanting (DAT) at the experimental field, Faculty of Agriculture, University of the Ryukyus, Okinawa, Japan. The results showed that water shortage from a rain-fed condition caused reductions, but not significant in plant height and SPAD of sugarcane varieties. The genetic variation in leaf area, yield components, partial and total biomass, and cane yield was found among the investigated varieties. The positive associations between total nitrogen uptake with total biomass production and cane yield suggested that higher nitrogen uptake supports better growth performance of sugarcane under rainfed conditions. From this study, NiF3 and Ni27 could be introduced as the promising sugarcane varieties for better growth performance and high nitrogen uptake under rain-fed conditions.
\end{abstract}

\section{Keywords}

Growth, nitrogen uptake, sugarcane, water stress

\section{Introduction}

Sugarcane produces an enormous biomass production with an average of approximately 40 tons per ha per year (Waclawovsky et al., 2010). In its life cycle, sugarcane consumes a huge amount of nitrogen $(\mathrm{N})$ and water for growth and development. The sugarcane productivity is mostly contributed by the stalk weight and stalk population. Water shortage at tillering and elongating phases reduces plant growth and plant population which leads to a decrease in the number of millable stalks. The low millable stalk number will result in losses of both cane and sugar yield (Dinh et al., 2017b). Therefore, water shortage at these phases becomes one of the most important limiting factors in sugarcane production. 
In most cases, $\mathrm{N}$ is often applied during tillering and early elongating phases to supply essential materials to critical processes such as photosynthesis, plant growth, leaf expansion, and tiller or sucker production. During these phases, $\mathrm{N}$ is easily lost from the soil through leaching and volatilization processes. $\mathrm{N}$ deficiency reduces the photosynthetic capacity, induces stunted growth, reduces stooling, and leads to low productivity (Schroeder et al., 2014, Dinh et al., 2017a; 2018). Moreover, in tropical and subtropical regions, sugarcane often confronts water-shortage from the limitation of water supply because most of the production areas are grown under rain-fed conditions. Water shortage during tillering and early elongating phases induces low tissue water status and interferes with water absorption followed by the reduction of nutrient uptake (Lopes et al., 2011; Dinh et al., 2014) and restricting enzyme activity in the assimilation and remobilization processes (Abayomi, 2001). Hence, it becomes one of the main reasons for $\mathrm{N}$ deficiency. Breeding for better growth and higher $\mathrm{N}$ uptake, especially under the limitation of water supplement during tillering and elongating phases, is crucial. The objective of this study was to evaluate the growth, biomass performance, and $\mathrm{N}$ uptake of twelve commercial sugarcane varieties, and to identify the relationship between $\mathrm{N}$ uptake and biomass production under water-limitation conditions.

\section{Materials and Methods}

\section{Experimental site}

The experiment was conducted at the experimental field, Faculty of Agriculture, University of the Ryukyus, Okinawa, Japan $\left(26^{\circ} 25^{\prime} \mathrm{N}, 127^{\circ} 45^{\prime} \mathrm{E}\right.$; altitude $\left.126 \mathrm{~m}\right)$ from April to October 2018. The experimental soil is Shimajiri Mahji red soil type with $\mathrm{pH} 6.2$ and total $\mathrm{N}$ content $0.11 \%$. The climatic conditions during the experimental period are shown in Figure 1 with the daily average air humidity and solar radiation ranging from 51.9 to $92.6 \%$ and from 16.3 to $337.2 \mathrm{~W} \mathrm{~m}^{-2}$, respectively. The daily average air temperature increased from 19.1 to $28.6^{\circ} \mathrm{C}$. Wind speed fluctuated from 0.6 to $5.0 \mathrm{~m}$ $\mathrm{s}^{-1}$. Total precipitation during the experimental period was $734.0 \mathrm{~mm}$, mainly from early June to mid-September with a small typhoon in early July.

\section{Crop management}

The experimental field was prepared by ploughing and harrowing one month before planting. Twelve commercial sugarcane varieties in Japan, namely NiF3, NiF8, Ni9, Ni12, Ni15, Ni17, Ni21, Ni22, Ni25, Ni27, Ni28, and Ni29, were used as experimental materials. The twomonth-old sugarcane seedlings were transplanted on April 19, 2018 with a distance of $120 \times 30 \mathrm{~cm}$ in row and plant interval, respectively. The surface drip tape (Adrilite, Adritec Group) with a distance of $30 \mathrm{~cm}$ between emitters, connected with an irrigation controller (Aqua Pro, Netafim Irrigation Equipment and Drip Systems, Israel) was installed in each sugarcane row to supply water immediately after transplanting. The irrigation pressure was kept at around 0.2 bar to control the water flow rate at approximately 1.5 $\mathrm{L} \mathrm{h}^{-1}$. Fertilizer was supplied 3 times at a ratio of 2.0:2.0:2.5 by $1300 \mathrm{~kg} \mathrm{ha}^{-1}$ of NPK 16:6:6 at 7, 30 , and 60 days after transplanting (DAT), respectively.

During the experiment period, hand weeding was carried out to protect the plants from the nutritional competition of weeds. Pests and diseases were frequently observed and controlled when occurring. Fipronil $(( \pm)-5$-amino-1-(2,6dichloro-a,a,a-trifluoro-p-tolyl)-4-

trifluomethylsulfinyl pryrazole-3-carbonitrile) $0.5 \%$ at the rate of $65 \mathrm{~kg} \mathrm{ha}{ }^{-1}$, and Chlorantraniliprole (3-bromo-N-(4-chloro-2methyl-6([methylamino]carbonyl)phenyl)-1-[3chloro-2-pyridinyl]-1H-pyrazole-5-

carboxamide) $10 \% \mathrm{w} \mathrm{v}^{-1}$ ) with a 1:5000 dilution ratio at the rate of $1000 \mathrm{~L} \mathrm{ha}^{-1}$ were applied as insecticides to control stem borers. Other crop management practices were applied following the cultivation manual for sugarcane (Okinawa Prefectural Government, 2015).

\section{Experimental design and soil moisture management}

The experiment was divided into two blocks: (i) a water-shortage block where sugarcane was grown under rain-fed conditions during tillering and elongating phases; and (ii) a control block 

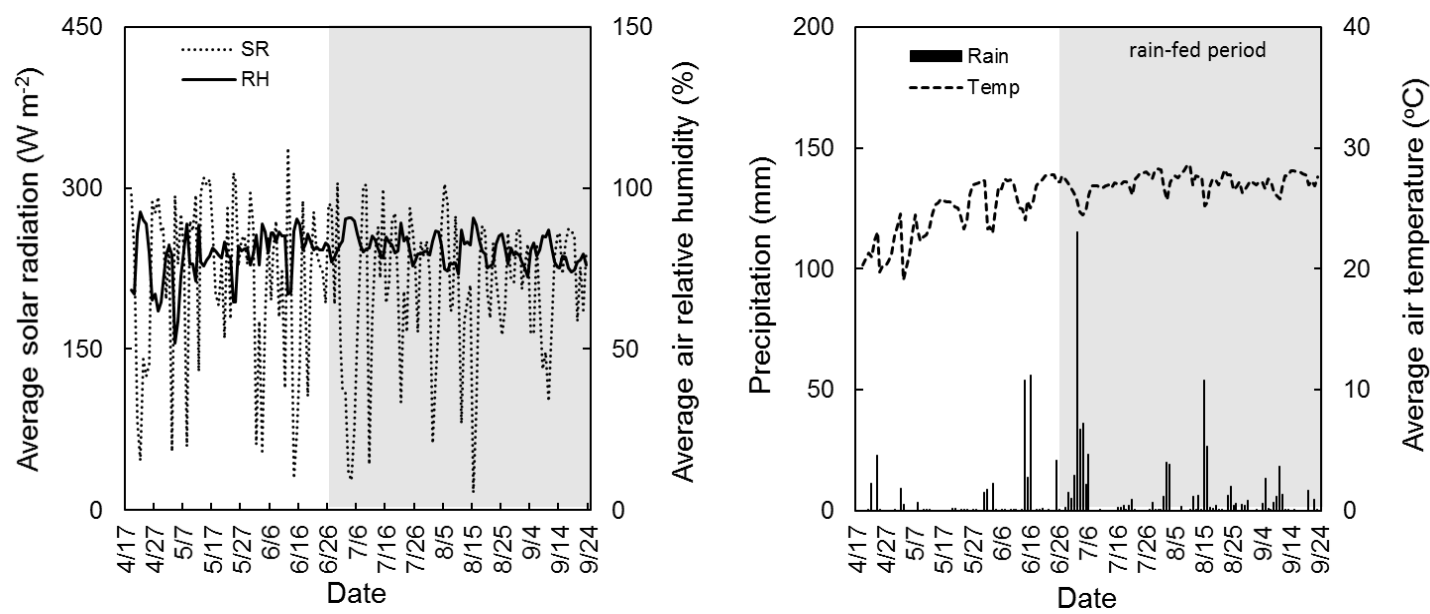

Figure 1. Weather conditions during the experimental period

where sugarcane was grown under full irrigation conditions. In each block, the same experimental design by a randomized complete block design with three replications was used. For the control block, soil moisture was maintained around field capacity at soil moisture potential ( $\mathrm{pF}$ value) of approximately 2.0 throughout the crop season. Soil matric potential value $(\mathrm{pF})$ was recorded at 10 -minute intervals by soil matric potential sensors (MPS-6, Decagon Devices Inc., USA) which were installed from 65 DAT between the third and fourth plants in each sugarcane row at a depth of $25 \mathrm{~cm}$ (Figure 2a). The total amount of water applied for each plot was calculated by crop water requirement $\left(\mathrm{ET}_{\text {crop }}\right)$ which was calculated following the methods described by Doorenbos \& Pruitt (1992) using the crop coefficient for Naha region as suggested by Hossain et al. (2005) and the reference evapotranspiration calculated according to Penman-Monteith equation (FAO, http://www. fao.org). For water-shortage block, water was withheld for 90 days from 70 DAT.

\section{Data collection}

From 30 DAT, plant height was measured from soil surface to top visual dewlap of the mother stalk at 10 days intervals. At the same time, SPAD was measured at the first fully expanded leaves of the sample plant of each treatment in all replications using a SPAD meter (SPAD-502, Minolta, Japan).
At 160 DAT, sample plants from the watershortage block were taken to compare agronomical parameters among sugarcane varieties. The aboveground parts of the sample plant were cut, and the whole plant leaf blades were separated to determine leaf fresh weight, the leaf sample of $250 \mathrm{~g}$ of fresh weight was taken to measure leaf area using leaf area meter (LI3100, LI-COR, Lincoln, Nebraska, USA). The total leaf area was converted by a sample leaf area from the ratio of fresh weights of the sample and total plant leaf. After removing leaf blades, the total stalks fresh weight, the number of stalks, stalk heights and diameter were determined. The stalk sample of $1 \mathrm{~kg}$ of fresh weight was taken to shred by a cutter grinder (S392, Jeffco, Jeffress Engineering, Australia). Then, $500 \mathrm{~g}$ of the sample was taken to determine the fresh weight and then squeezed by a hydraulic press machine to determine fresh bagasse weight. Bagasse and leaf samples, then, were dried at $80^{\circ} \mathrm{C}$ for $48 \mathrm{~h}$ to determine dry weights. After that, total leaf dry weight and stalk dry weight were converted from leaf sample dry weight by the ratio of fresh weights of the sample to total plant leaf, and sample bagasse dry weight by the ratio of grinder sample fresh weight to total stalk fresh weight. Total plant dry weight was calculated by the sum of total leaf and stalk dry weight.

To determine total $\mathrm{N}$ uptake, the dry leaf and bagasse sample were ground separately by a power grinder (MN-02C Master T-429, Taiwan). Then, $25 \mathrm{mg}$ of sample was taken to determine $\mathrm{N}$ 
concentration using an N/C analyzer (NC-90A, Shimadzu, Japan). Total N uptake was calculated by total leaf and stalk $\mathrm{N}$ content.

\section{Data analysis}

The data were subjected to analysis of variance according to a randomized complete block design using Statistix 8.0. The T-test was used to compare the means between two treatment blocks. The least significant difference (LSD) test was used to compare the means among sugarcane varieties.

\section{Results}

\section{Effect of water shortage on sugarcane growth}

During the first 2 months after transplanting, the average plant height increasing the rate of sugarcane varieties was slow with $1.0 \mathrm{~cm} \mathrm{day}^{-1}$ in both water treatment blocks (Figure 2b). It, then, rapidly increased with the highest rate of $3.5 \mathrm{~cm}$ day $^{-1}$ during the period from 63 (June 21) to 72 DAT (June 30). Afterwards, the increasing rate in the control block was reduced and maintained stable at around $2 \mathrm{~cm}$ plant $^{-1}$. In the watershortage block, the increasing rate was lower than that of the control block during the period from 81 (July 9) to 102 DAT (July 30). The clearest difference was found during the most stressful period when $\mathrm{pF}$ reached the highest values from 92 to 102 DAT. Subsequently, the plant height increasing rate of sugarcane plant in the stress block recovered and maintained at the same rate as that of the control block. The water stress during the short period from 80 to 105 DAT might have a certain effect on increasing the rate of the average plant height of sugarcane varieties, which resulted in lower plant height in the water-shortage treatment in comparison with that in the control treatment (Figure 2c). However, because of the appearance of rainfall alternated in the water-shortage period, the difference in plant height between the two water regime treatments was not significant.

From Figure 2d, it can be seen that there was a downward trend of SPAD of sugarcane varieties from 52 at the beginning (May 17) to 46 at 63 DAT (June 21). Following that, SPAD was maintained at the same levels for 20 days before declining to 42 on July 20 (92 DAT). The difference between SPAD of the two water treatment blocks was found to be clearer, but not significant, from this date with lower SPAD values of the watershortage treatment as compared to that of the control treatment. Since 123 DAT (August 20), SPAD of the water-shortage treatment became similar to that of the control.

\section{Variation in agronomical parameters, biomass, and $\mathbf{N}$ uptake of sugarcane varieties}

Because no difference in the growth of the sugarcane plant between water stress and control treatment (statistical not shown) was found, the result for agronomical parameters, biomass, and $\mathrm{N}$ uptake of sugarcane varieties were only shown in rain-fed treatment. Several agronomical parameters of sugarcane varieties are shown in Table 1. Sugarcane varieties tillered concentrative from 26 to 42 DAT. Ni29 was the earliest tillering variety followed by $\mathrm{Ni} 27$ with 26 and 28 DAT, respectively. Ni21 was the latest tillering variety, later than other varieties from 5 to 16 days. There were significant differences in leaf area, tiller number, stalk length, stalk fresh weight, and stalk perimeter. Leaf areas of sugarcane varieties ranged from 1.40 to $2.53 \mathrm{~m}^{2}$, where NiF8 had the largest leaf area, significantly higher than Ni12, Ni15, Ni21, Ni25, and Ni29. Tiller number ranged from 3.7 to 8.0 tillers plant ${ }^{-1}$. NiF8 had the highest tiller number, whereas Ni21 showed the lowest one, but only significantly lower than NiF8 and Ni9. Stalk height of sugarcane varieties ranged from 216.7 to $260.5 \mathrm{~cm}$, where $\mathrm{NiF} 3$ showed the highest value and significantly higher than other varieties, except for NiF8, Ni22, Ni27, and Ni28. Meanwhile, Ni15 had the lowest stalk height and significantly lower than the five above varieties. NiF3 also showed the highest values for fresh stalk weight $\left(1.23 \mathrm{~kg} \mathrm{stalk}^{-1}\right)$ and stalk diameter $(2.6 \mathrm{~cm})$, significantly higher than all other varieties, except for Ni21 and Ni27 in stalk diameter. Meanwhile, NiF8 showed the lowest values for both stalk weight and diameter.

The differences among sugarcane varieties were significant in leaf dry weight, stalk dry 

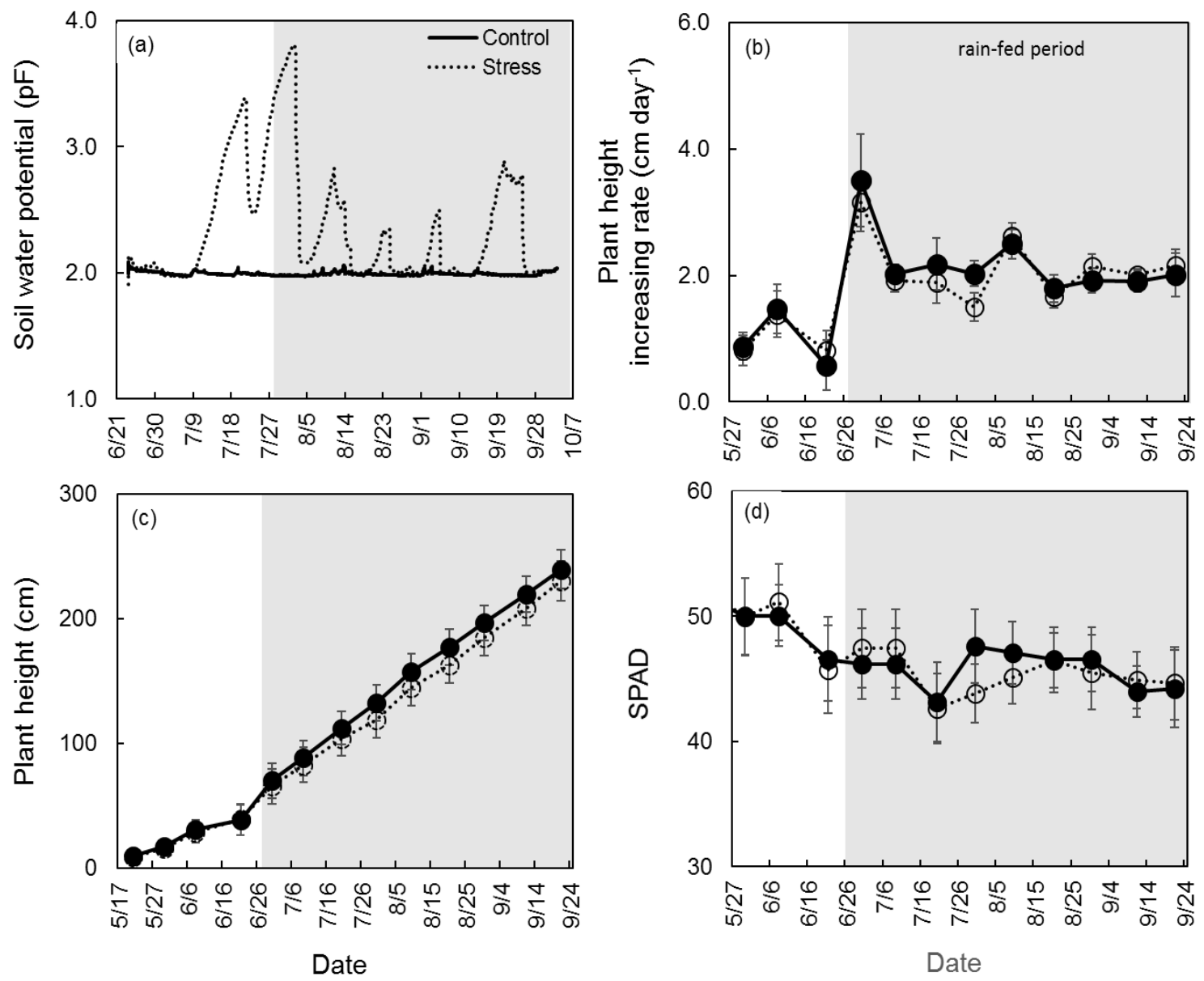

Figure 2. Soil water potential (a), plant height increasing rate (b), plant height (c), and SPAD (d) of sugarcane in water-shortage block (open shape) and control block (close shape)

weight, total dry weight, total $\mathrm{N}$ uptake, and cane yield, but not significant in SPAD (Table 2). $\mathrm{NiF} 8, \mathrm{Ni}$, and Ni27 showed the highest values for leaf dry weight, significantly higher than Ni12, Ni15, Ni21, and Ni25. Meanwhile, NiF3 and Ni27 showed the highest values for dry stalk weight, significantly higher than Ni12, Ni15, $\mathrm{N} 21$, Ni25, and Ni29. The total dry weight of $\mathrm{NiF} 3$ was the highest, which was followed by $\mathrm{Ni} 27$ and NiF8, significantly higher than Ni12, Ni15, Ni17, Ni21, and Ni25. Ni27 and NiF3 showed the highest total $\mathrm{N}$ uptake values, significantly higher than Ni21 and Ni25. Ni27 followed by $\mathrm{NiF} 3$ showed the highest values for cane yield which were significantly higher than other varieties except for $\mathrm{NiF} 8, \mathrm{Ni}$, Ni17, Ni28, and Ni29.

There were significant positive correlations among agronomical and growth parameters, except for stalk diameter with total dry weight $(\mathrm{r}$ $\left.=0.16^{\mathrm{ns}}\right)$ and stalk number with cane yield $(\mathrm{r}=$ $\left.0.30^{\mathrm{ns}}\right)$. A positive correlation was also found in the relationship between total $\mathrm{N}$ uptake with total dry weight $\left(\mathrm{r}=0.91^{* *}\right)$ and cane yield $(\mathrm{r}=$ $0.89 * *$ ) (Table 3).

\section{Discussion}

\section{Effect of water shortage on sugarcane growth}

In general, plant growth presented in plant elongating or leaf expansion is inhibited because of lacking energy and materials to support cell division and elongation processes when plants are under water-deficit conditions. Many previous studies demonstrated harmful effects of water stress on plant height, plant elongating rate, leaf number, leaf area index, and SPAD (Barbosa et al., 2015; Begum et al., 2012; Begum \& Islam, 
Variations in growth performance and nitrogen uptake of sugarcane cultivars under rain-fed conditions

Table 1. Tillering date, tiller number, stalk height, stalk fresh weight, and stalk diameter of sugarcane varieties under rain-fed conditions

\begin{tabular}{|c|c|c|c|c|c|c|}
\hline Varieties & $\begin{array}{l}\text { Tillering date } \\
\text { (DAT) }\end{array}$ & $\begin{array}{c}\text { Leaf area } \\
\left(\mathrm{m}^{2}\right)\end{array}$ & $\begin{array}{c}\text { Tiller number } \\
\text { plant }^{-1}\end{array}$ & $\begin{array}{l}\text { Stalk height } \\
\qquad(\mathrm{cm})\end{array}$ & $\begin{array}{l}\text { Single stalk } \\
\text { weight }(\mathrm{kg})\end{array}$ & $\begin{array}{l}\text { Stalk diameter } \\
(\mathrm{cm})\end{array}$ \\
\hline NiF3 & 37 & $2.17^{a b c}$ & $4.3^{\mathrm{bc}}$ & $260.5^{a}$ & $1.23^{a}$ & $2.6^{\mathrm{a}}$ \\
\hline NiF8 & 30 & $2.53^{a}$ & $8.0^{\mathrm{a}}$ & $248.2^{\mathrm{abc}}$ & $0.47^{e}$ & $1.5^{\mathrm{e}}$ \\
\hline $\mathrm{Ni9}$ & 32 & $2.20^{\mathrm{ab}}$ & $5.7^{b}$ & $233.4^{\mathrm{b}-\mathrm{e}}$ & $0.73^{\mathrm{cd}}$ & $2.0^{d}$ \\
\hline $\mathrm{Ni} 12$ & 35 & $1.87^{\mathrm{bcd}}$ & $4.3^{\mathrm{bc}}$ & $220.4^{\text {de }}$ & $0.80^{\mathrm{cd}}$ & $2.2^{\mathrm{bcd}}$ \\
\hline $\mathrm{Ni15}$ & 36 & $1.40^{d}$ & $4.7^{\mathrm{bc}}$ & $216.7^{e}$ & $0.73^{\mathrm{cd}}$ & $2.1^{\mathrm{cd}}$ \\
\hline $\mathrm{Ni17}$ & 34 & $2.00^{\mathrm{a}-\mathrm{d}}$ & $4.3^{\mathrm{bc}}$ & $224.0^{\mathrm{b}-\mathrm{e}}$ & $0.90^{\mathrm{bc}}$ & $2.3^{b}$ \\
\hline $\mathrm{Ni} 21$ & 42 & $1.57^{c d}$ & $3.7^{c}$ & $225.1^{\mathrm{b}-\mathrm{e}}$ & $0.87^{\mathrm{bcd}}$ & $2.4^{\mathrm{ab}}$ \\
\hline $\mathrm{Ni} 22$ & 31 & $1.93^{\mathrm{a}-\mathrm{d}}$ & $5.0^{\mathrm{bc}}$ & $236.7^{\mathrm{a}-\mathrm{d}}$ & $0.70^{d}$ & $2.0^{d}$ \\
\hline $\mathrm{Ni} 25$ & 36 & $1.63^{\mathrm{bcd}}$ & $4.0^{c}$ & $223.2^{\text {cde }}$ & $0.77^{\mathrm{cd}}$ & $2.2^{\mathrm{bcd}}$ \\
\hline $\mathrm{Ni} 27$ & 28 & $2.17^{a b c}$ & $5.0^{\mathrm{bc}}$ & $250.9^{\mathrm{ab}}$ & $1.03^{b}$ & $2.4^{\mathrm{ab}}$ \\
\hline $\mathrm{Ni} 28$ & 31 & $2.00^{a-d}$ & $5.0^{\mathrm{bc}}$ & $244.3^{a-d}$ & $0.86^{\mathrm{bcd}}$ & $2.2^{\mathrm{bcd}}$ \\
\hline $\mathrm{Ni} 29$ & 26 & $1.53^{d}$ & $5.0^{\mathrm{bc}}$ & $223.5^{\text {cde }}$ & $0.90^{\mathrm{bc}}$ & $2.3^{b c}$ \\
\hline CV\% & - & 19.3 & 19.1 & 6.8 & 13.5 & 6.3 \\
\hline $\begin{array}{c}\text { Significance } \\
\text { level }\end{array}$ & - & * & $* *$ & * & $* *$ & $* *$ \\
\hline
\end{tabular}

Note: * and ${ }^{* *}$ mean non-significant and significant at $P<0.05$ and $P<0.01$, respectively. Different small letters in the same column show significance between sugarcane varieties at the same water levels at $P<0.05$ by LSD.

Table 2. SPAD, stalk dry weight, leaf dry weight, total dry weight, total nitrogen uptake, and cane yield of sugarcane varieties under rain-fed conditions

\begin{tabular}{|c|c|c|c|c|c|c|}
\hline Varieties & SPAD & $\begin{array}{l}\text { Stalk dry } \\
\text { weight } \\
\left(\text { g plant }^{-1}\right)\end{array}$ & $\begin{array}{l}\text { Leaf dry weight } \\
\quad\left(\text { g plant }^{-1}\right)\end{array}$ & $\begin{array}{l}\text { Total dry } \\
\text { weight } \\
\left(\text { g plant }^{-1}\right)\end{array}$ & $\begin{array}{l}\text { Total N uptake } \\
\quad\left(\text { g plant }^{-1}\right)\end{array}$ & $\begin{array}{l}\text { Cane yield } \\
\text { (tones ha-1) }^{-1}\end{array}$ \\
\hline NiF3 & $42.2^{\mathrm{c}}$ & $585.3^{a}$ & $201.1^{\mathrm{ab}}$ & $786.4^{\mathrm{a}}$ & $4.0^{\mathrm{ab}}$ & $138.5^{\mathrm{ab}}$ \\
\hline NiF8 & $48.5^{\mathrm{a}}$ & $472.1^{\mathrm{abc}}$ & $238.5^{a}$ & $710.6^{\mathrm{abc}}$ & $3.7^{\mathrm{abc}}$ & $100.1^{b c}$ \\
\hline $\mathrm{Ni9}$ & $44.6^{\mathrm{abc}}$ & $418.0^{\mathrm{ab}}$ & $234.5^{a}$ & $652.5^{a-d}$ & $3.8^{\mathrm{ab}}$ & $114.3^{\mathrm{abc}}$ \\
\hline $\mathrm{Ni12}$ & $44.8^{\mathrm{abc}}$ & $371.8^{\mathrm{bc}}$ & $172.0^{\mathrm{b}}$ & $543.8^{\mathrm{c}-\mathrm{f}}$ & $3.1^{\mathrm{bcd}}$ & $95.0^{c}$ \\
\hline $\mathrm{Ni15}$ & $45.9^{a b c}$ & $353.5^{c}$ & $154.0^{\mathrm{b}}$ & $507.5^{\text {def }}$ & $3.0^{\mathrm{bcd}}$ & $94.2^{\mathrm{c}}$ \\
\hline $\mathrm{Ni17}$ & $42.9^{c}$ & $383.7^{\mathrm{abc}}$ & $212.4^{\mathrm{ab}}$ & $596.0^{b-f}$ & $3.2^{\mathrm{bcd}}$ & $108.6^{\mathrm{abc}}$ \\
\hline $\mathrm{Ni} 21$ & $44.2^{\mathrm{abc}}$ & $276.6^{c}$ & $160.0^{\mathrm{b}}$ & $436.6^{\dagger}$ & $2.8^{\text {cd }}$ & $87.0^{c}$ \\
\hline $\mathrm{Ni} 22$ & $48.0^{\mathrm{ab}}$ & $434.7^{\mathrm{abc}}$ & $203.5^{\mathrm{ab}}$ & $638.2^{\mathrm{a}-\mathrm{e}}$ & $3.7^{\mathrm{abc}}$ & $98.3^{c}$ \\
\hline $\mathrm{Ni} 25$ & $42.9^{c}$ & $302.5^{c}$ & $157.1^{\mathrm{b}}$ & $459.6^{e f}$ & $2.7^{d}$ & $83.8^{c}$ \\
\hline $\mathrm{Ni} 27$ & $43.1^{c}$ & $528.3^{a}$ & $238.9^{a}$ & $767.2^{\mathrm{ab}}$ & $4.3^{\mathrm{a}}$ & $142.1^{\mathrm{a}}$ \\
\hline $\mathrm{Ni} 28$ & $43.0^{c}$ & $405.4^{\mathrm{abc}}$ & $197.8^{\mathrm{ab}}$ & $603.2^{a-f}$ & $3.5^{\mathrm{a}-\mathrm{d}}$ & $116.3^{\mathrm{abc}}$ \\
\hline $\mathrm{Ni} 29$ & $43.6^{\mathrm{bc}}$ & $410.3^{b c}$ & $205.5^{\mathrm{ab}}$ & $615.8^{a-f}$ & $3.8^{\mathrm{ab}}$ & $122.7^{\mathrm{abc}}$ \\
\hline CV\% & 5.9 & 19.5 & 18.6 & 18.7 & 16.1 & 22.0 \\
\hline $\begin{array}{c}\text { Significance } \\
\text { level }\end{array}$ & Ns & ** & * & * & * & * \\
\hline
\end{tabular}

Note: $n s,{ }^{*}$, and ${ }^{* *}$ mean non-significant, significant at $P<0.05$ and $P<0.01$, respectively. Different small letters in the same column show significant differences between sugarcane varieties at the same water levels at $P<0.05$ by $L S D$. 
Table 3. Correlation of agronomical and growth parameters with biomass production $(n=36)$

\begin{tabular}{|c|c|c|}
\hline Parameters & Total dry weight & Cane yield \\
\hline Stalk number & $0.54^{\star \star}$ & $0.30^{\mathrm{ns}}$ \\
\hline Stalk height & $0.56^{\star \star}$ & $0.41^{*}$ \\
\hline Stalk diameter & $0.16^{\mathrm{ns}}$ & $0.47^{\star *}$ \\
\hline Stalk weight & $0.56^{\star *}$ & $0.58^{* *}$ \\
\hline Leaf area & $0.83^{\star *}$ & $0.60^{\star *}$ \\
\hline Leaf dry weight & $0.88^{\star \star}$ & $0.72^{\star \star}$ \\
\hline Shoot dry weight & $0.98^{\star *}$ & $0.87^{\star *}$ \\
\hline Total N uptake & $0.91^{\star \star}$ & $0.89^{\star *}$ \\
\hline
\end{tabular}

Note: ns, *, and ** mean non-significant, significant at $P<0.05$ and $P<0.01$, respectively.

2012; Dinh et al., 2017a; Ethan et al., 2016; Jangpromma et al., 2010; Robertson et al., 1999; Silva et al., 2007; Zhao et al., 2010). In this study, the decrease of plant height increasing rate was recorded during the most severe waterdeficit period of 81 to 120 DAT, which led to a lower plant height of water-shortage treatment in comparison to that of control treatment from 81 DAT until the end of the experiment. SPAD seemed less sensitive to water-shortage than plant height. The lower SPAD of stress treatment was observed in a later period from 102 to 112 DAT, then becoming similar to SPAD of control treatment from 123 DAT (Figure 2d). However, the difference in plant height and SPAD after the experimental period between the two water treatments was not significant. A previous study suggested that starting irrigating when $\mathrm{pF}$ increases to 2.8 may avoid plant growth reduction (Dinh et al., 2019). Therefore, water shortage (totally around 20 days) in this study is too short to have any significant impact on the growth of sugarcane. Moreover, the disturbance from rainfall, especially during the later period of the experiment, may give sugarcane plants the chance to recover. Jangpromma et al. (2010) and Dinh et al. (2017b) also found the recovery of SPAD after the drought stress period. Jangpromma et al. (2012) agreed that mild drought stress during the short period from 90 to 100 days after planting did not have any noticeable effects on the relative growth rate of sugarcane plant height.

\section{Variation in agronomical parameters, biomass, and $\mathbf{N}$ uptake of sugarcane varieties}

In this study, variation in growth, yield component, biomass, cane yield as well as total $\mathrm{N}$ uptake was found among investigated varieties. Genetic variation in leaf area, cane yield and yield components, partial and total biomass was also found in sugarcane varieties by; Dinh et al. (2018); Li et al. (2017); Jackson et al. (2016); Luo et al. (2014); Basnayake et al. (2012); and Ramesh (2000). The evidence of variation in $\mathrm{N}$ uptake of sugarcane varieties was reported by Schumann et al. (1998) and Ranjith and Meinzer (1997). Under pot conditions, Dinh et al. (2018) did not found any differences in total $\mathrm{N}$ uptakes among five similar sugarcane varieties, NiF3, Ni9, Ni17, Ni21, and Ni22, in both drought stress and non-stress treatments. In this study, the significant difference of $\mathrm{N}$ uptake was found only between $\mathrm{NiF} 3$ and Ni21; whereas, no difference was found among these two varieties with the other three varieties.

In this study, total dry matter accumulation had a positive correlation with stalk number, stalk height, and stalk weight (Table 3). Tena et al. (2016) and Silva et al. (2008) also found a positive correlation among yield components (stalk number, stalk height, stalk diameter and stalk weight) and productivity under watershortage and normal irrigation conditions, respectively. It is suggested that sugarcane with high stalk number, stalk height, stalk weight, and leaf area has high potential for high dry matter accumulation. Moreover, because of the correlation coefficients of stalk number and stalk 
weight with total dry weight were almost similar $\left(\mathrm{r}=0.54^{* *}\right.$ and $\mathrm{r}=0.56^{* *}$, respectively), the difference in total dry weight among varieties of stalk number and stalk weight type was not noticeable. This point of view is in line with Ehara et al. (1994). In the case of cane yield, the most contribution came from stalk weight $(\mathrm{r}=$ $0.58 * *)$. In this study, both leaf dry weight and stalk dry weight directly contributed to total plant dry weight and cane yield with a higher correlation coefficient of stalk dry weight $(\mathrm{r}=$ $0.98 * *$ and $\mathrm{r}=0.87 * *)$ than that of dry leaf weight $\left(\mathrm{r}=0.88^{* *}\right.$ and $\left.\mathrm{r}=0.72 * *\right)$ with total dry weight and cane yield, respectively. It means that stalk has a larger contribution to total biomass production and cane yield than leaf. Furthermore, another finding of this study is that there were positive correlations between total $\mathrm{N}$ uptake and total dry matter accumulation and between total $\mathrm{N}$ uptake and cane yield. It agreed and supported the suggestion of Dinh et al. (2017a) that higher $\mathrm{N}$ uptake could support better biomass and yield performance of sugarcane under both irrigation and water shortage conditions. Under the same $\mathrm{N}$ application conditions, better $\mathrm{N}$ uptake or $\mathrm{N}$ use efficiency could support better growth and crop yield (Acreche, 2017; Calif \& Edgecombe, 2015). Higher $\mathrm{N}$ use efficiency could also help plants attain higher ability to confront water deficit (Dinh et al., 2017a). From this study, NiF3 and Ni27 could be introduced as the promising varieties for higher growth performance and $\mathrm{N}$ uptake under rain-fed conditions.

\section{Conclusions}

The results indicated that there were no significant reductions in the growth of sugarcane under rain-fed conditions compared to irrigated conditions. Under rain-fed conditions, the genetic variation was found among twelve sugarcane varieties in leaf area, yield components, partial and total biomass, total nitrogen uptake, and cane yield. The correlation coefficients among agronomical and growth parameters were positive and significant. Better growth performance of sugarcane could be supported by higher nitrogen uptake under rainfed conditions. NiF3 and Ni27 were the best varieties for growth performance and nitrogen uptake under rain-fed conditions.

\section{References}

Abayomi Y. A. (2001). Nitrogen use efficiency and drought tolerant capacity of two commercial sugarcane cultivars. Journal of Agricultural Science and Technology. 9-11: 9-15.

Acreche M. M. (2017). Nitrogen-, water- and radiation-use efficiencies affected by sugarcane breeding in Argentina. Plant Breeding. 1-8. DOI: 10.1111/pbr.12440.

Barbosa A. M., Guidorizi K. A., Catuchi T. A., Marques T. A., Ribeiro R. V. \& Souza G. M. (2015). Biomass and bioenergy partitioning of sugarcane plants under water deficit. Acta Physiologiae Plantarum. 37: 142.

Basnayake J., Jackson P. A., Inman-Bamber N. G. \& Lakshmanan P. (2012). Sugarcane for water-limited environments. Genetic variation in cane yield and sugar content in response to water stress. Journal of Experimental Botany. 63: 6023-6033.

Begum M. K. \& Islam M. S. (2012). Effect of drought stress on yield and yield components of sugarcane. Journal of Agroforestry and Environment. 6: 105-109.

Calif D. \& Edgecombe M. (2015). Study shows nitrogen use efficiency trait increase biomass of sugarcane. Retrieved from, 2017.

Dinh T. H, Kaewpradit W., Jogloy S., Vorasoot N. \& Patanothai A. (2014). Nutrient uptake of peanut genotypes with different levels of drought tolerance under midseason drought. Turkish Journal of Agriculture and Forestry. 38: 495-505.

Dinh T. H., Watanabe K., Takaragawa H., Nakabaru M. \& Kawamitsu Y. (2017a). Photosynthetic response and nitrogen use efficiency of sugarcane under drought stress conditions with different nitrogen application levels. Plant Production Science. 20: 412-422.

Dinh T. H., Watanabe K., Takaragawa H. \& Kawamitsu Y. (2017b). Effects of drought stress at early growth stage on response of sugarcane to different nitrogen application. Sugar Tech. 20: 420-430.

Dinh T. H., Takaragawa H. \& Kawamitsu Y. (2018). Nitrogen use efficiency and drought tolerant ability of various sugarcane varieties under drought stress at early growth stage. Plant Production Science. DOI: 10.1080/1343943X.2018.1540277.

Dinh T. H., Takaragawa H., Watanabe K., Nakabaru M. \& Kawamitsu Y. (2019). Leaf photosynthetic response to change of soil moisture content in sugarcane. Sugar 
Tech. DOI:10.1007/s12355-019-00735-8.

Doorenbos J. \& Pruitt W. O. (1992). Calculation of crop water requirements. In: Crop water requirements. FAO Irrigation and Drainage Paper No. 24 (Roma). 1-65.

Ehara H., Tsuchiya M. \& Takamura T. (1994). Growth and dry matter production of sugar cane in warm temperate zone of Japan. Japanese Journal of Tropical Agriculture. 38: 51-58.

Ethan S., Olagoke O. \& Yunusa A. (2016). Effect of deficit irrigation on growth and yield of sugarcane. Direct Research Journal of Agriculture and Food Science. 4: 122-126.

FAO (2018). Chapter 2- FAO Penman-Monteith equation. Retrieved from http://www.fao.org/docrep /X0490E/x0490e06.htm on January 10, 2018.

Hossain M. A., Ueno M., Maeda K. \& Kawamitsu Y. (2005). Potential evapotranspiration and crop coefficient estimates for sugarcane in Okinawa. Journal of Agricultural Meteorology. 60: 573-576.

Jackson P., Basnayake J., Inman-Bamber N.G., Lakshmanan P., Natarajan S. \& Stokes C. (2016). Genetic variation in transpiration efficiency and relationships between whole plant and leaf gas exchange measurements in Saccharum spp. and related germplasm. Journal of Experimental Botany. 67: 861871.

Jangpromma N., Songrsi P., Thammasiririak S. \& Jaisil P. (2010). Rapid assessment of chlorophyll content in sugarcane using a SPAD chlorophyll meter across different water stress conditions. Asian Journal of Plant Science. 9: 368-374.

Jangpromma N., Thammasirirak S., Jaisil P. \& Songsri P. (2012). Effects of drought and recovery from drought stress on above ground and root growth, and water use efficiency in sugarcane (Saccharum officinarum L.). Australian Journal of Crop Science. 6: 1298-1304.

Li C., Jackson P., Lu X., Xu C., Cai Q., Basnayake J., Lakshmanan P., Ghannoum O. \& Fan Y. (2017). Genotypic variation in transpiration efficiency due to differences in photosynthetic capacity among sugarcane-related clones. Journal of Experimental Botany. 68: 2377-2385.

Lopes M., Araus J. L., van Heerden P. D. R. \& Foyer C. H. (2011). Enhancing drought tolerance in C4 crops. Journal of Experimental Botany. 62: 3135- 3153.
Luo J., Pan Y. B., Xu L., Zhang Y., Zhang H., Chen R. \& Que Y. (2014). Photosynthetic and canopy characteristics of different varieties at the early elongation stage and their relationships with the cane yield in sugarcane. The Scientific World Journal. DOI: 10.1155/2014/707095.

Okinawa Prefectural Government, Department of Agriculture, Forestry and Fisheries (2015). Cultivation Manual for Sugarcane. Retrieved from http://www.pref.okinawa.jp/ site/norin/togyo/kibi/mobile/ documents/07saibaigoyomi.pdf on October 12, 2017.

Ranjith S. \& Meinzer F. C. (1997). Physiological correlates of variation in nitrogen-use efficiency in two contrasting sugarcane cultivars. Crop Science. 37: 818-825.

Schroeder B. L., Salter B., Moody P. W., Skocaj D. M. \& Thorburn P. J. (2014). Evolving nature of nitrogen management in the Australian sugar Industry. In: Bell M. J. (Ed.). A review of nitrogen use efficiency in sugarcane. Sugar Research Australia Ltd. eLibary pp.1588. Retrieved from http://elibrary.sugarreserach.com.au on December 1, 2015.

Schumann A. W., Meyer J. H. \& Nair S. (1998). Evidence for different nitrogen use efficiencies of selected sugarcane varieties. Proceedings of South African Sugar Technologists' Association. 72: 77-80.

Silva M. A., Jifon J. L., Silva J. A. G. \& Sharma V. (2007). Use of physiological parameters as fast tools to screen for drought tolerance in sugarcane. Brazilian Journal of Plant Physiology. 19: 193-201.

Silva M. A., Silva J. A. G., Enciso J., Sharma V. \& Jifon J. (2008). Yield components as indicators of drought tolerance of sugarcane. Scientia Agricola (Piracicaba, Braz.). 65: 620-627.

Tena E., Mekbib F. \& Ayana A. (2016). Correlation and path coefficient analyses in sugarcane genotypes of Ethiopia. American Journal of Plant Sciences. 7: 1490-1497.

Waclawovsky A. J., Sato P. M., Lembke C. G., Moore P. H. \& Souza G. M. (2010). Sugarcane for bioenergy production: an assessment of yield and regulation of sucrose content. Plant Biotechnology Journal. 8: 263-276.

Zhao D., Barry G. \& Comstock J. C. (2010). Sugarcane response to water-deficit stress during early growth on organic and sand soils. American Journal of Agricultural and Biological Science. 5: 403-414. 